\title{
Human exposure risk to heavy metals through groundwater used for drinking in an intensively irrigated river delta
}

\author{
E. Vetrimurugan ${ }^{1} \cdot$ K. Brindha ${ }^{2} \cdot$ L. Elango ${ }^{3} \cdot$ Osman Muzi Ndwandwe $^{4}$
}

Received: 31 March 2016/Accepted: 1 September 2016/Published online: 12 September 2016

(c) The Author(s) 2016. This article is published with open access at Springerlink.com

\begin{abstract}
Drinking water containing heavy metals above the maximum permissible limits cause potential risk to human health. The aim of this study was to determine the groundwater suitability for drinking use based on heavy metal concentration and the associated human exposure risk in an intensively irrigated part of the Cauvery river basin, Tamil Nadu, India. Sixteen heavy metals analysed were in the order of dominance of chromium $<$ zinc $<$ copper $<$ cadmium $<$ cobalt $<$ iron $<$ aluminium $<$ nickel $<$ titanium $<$ zirconium $<$ boron $<$ silver $<$ manganese $<$ lead $<$ lithium $<$ silicon in groundwater. Chromium and zinc were within permissible limits of the Bureau of Indian Standards for drinking water quality, and silver, lead and nickel were above limits in all the groundwater samples. In less than $50 \%$ of the groundwater samples, aluminium, boron, cadmium, copper, iron and manganese exceeded their individual permissible limits. Heavy metal pollution index based on 11 heavy metals indicated that groundwater quality of this area is poor-to-unsuitable. Non-carcinogenic risk for humans due to ingestion of groundwater through drinking water pathway was very high for infants, children and adults. Silver, lead, nickel, cadmium and manganese largely contributed to the health hazard. Sources of heavy
\end{abstract}

L. Elango

elango34@hotmail.com; elango@annauniv.edu

1 Department of Hydrology, University of Zululand, Kwa Dlangezwa 3886, South Africa

2 International Water Management Institute, Vientiane, Lao PDR

3 Department of Geology, Anna University, Chennai 600025 , India

4 Departments of Physics and Engineering, University of Zululand, Kwa Dlangezwa 3886, South Africa metals were identified to be geological and from human activities, i.e., application of fertilizers in agricultural fields, seawater intrusion due to intensive pumping for agriculture and wastewater from industries. Groundwater and surface water in this area pose large threat due to high levels of heavy metals, and it is necessary to avoid this water for drinking due to potential risk of health hazard. This study also demonstrated the application of HPI and human exposure hazard index to study the groundwater quality based on heavy metals' concentration.

Keywords Heavy metal pollution index - Factor analysis . Hazard index · Groundwater - Surface water - Coastal area . Cauvery river basin $\cdot$ India

\section{Introduction}

Water used for drinking contains small quantities of heavy or trace metals that help in normal functioning of the human body but, in excess, can be toxic to human health. These heavy metals reach the human system through ingestion in the form of food and water. Where treated packaged water is used for drinking, the presence of these metals is monitored and hence may not be of potential risk to human health. However, in several regions of the developing world, groundwater pumped from private wells is directly used for domestic purpose, including drinking. This poses a great threat in a rapidly urbanising world and results in serious concerns on the quality of water resources. In developing countries such as India, people depend on groundwater and surface water resources for domestic use, including drinking, as piped water supply is limited (Brindha et al. 2014). Hence, it is essential to monitor the suitability of water for these activities. Understanding the 
concerns due to presence of heavy metals, many studies have been carried out in groundwater (Isa et al. 2014; Li et al. 2015; Ashraf et al. 2015), surface water (Varol and Şen 2012; Thuong et al. 2013), soil (Zhao et al. 2012; Li et al. 2014), sediments (Varol 2011; Chabukdhara and Nema 2012) and plants and vegetables (Sharma et al. 2007; Luo et al. 2011; Yousaf et al. 2016).

There are various sources for the occurrence of these heavy metals in the environment. Regions having rich ore deposits of certain metals tend to have these metals in groundwater due to the naturally occurring rock-water interaction. Arsenic is one such widely known lethal metal that occurs naturally in soil and causes severe health issues around the world especially affecting millions of lives in Asia (Fendorf et al. 2010; McCarty et al. 2011). Mining of metals from the ores and subsequent milling processes to remove the unwanted materials may also lead to the presence of such metals in soil and water around these areas (Stamatis et al. 2001; Bird et al. 2009). Distribution of heavy metals in water and soil nearby gold (Al-Hobaib et al. 2013), iron ore (Jahanshahi and Zare 2015), uranium (Giri et al. 2010; Brindha and Elango 2013, 2014), chromite (Krishna et al. 2013), antimony (Fu and Wei 2013) and polymetallic ( $\mathrm{Xu}$ et al. 2015) mines have also been examined.

Heavy metals usually occur in small amounts in groundwater around industrial areas that use variety of chemicals in the manufacture of batteries, paints, pharmaceutical products, leather processing, agrochemicals, etc. These industries dispose the treated/partially treated wastewater that do/do not meet the standards in the surface water bodies such as rivers, lakes, ponds and into the sea in coastal areas. Contamination due to suite of heavy metals is also commonly reported around landfills (Bakis and Tuncan 2011; Lu et al. 2016). The other important contamination route is through excessive application of agrochemicals that are retained in the unsaturated zone and reach groundwater through irrigation return flow. Accumulation of the bio-toxic heavy metals in crops and subsequent transport in the food chain pose potential risk to human health. Hence, several studies have been conducted on these lines (Nouri et al. 2008; Wongsasuluk et al. 2014; Lu et al. 2016).

This study was carried out in a part of the Cauvery river basin, Tamil Nadu, India (Fig. 1). Past studies in different parts of the Cauvery river basin which originates in Karnataka state and extends till Tamil Nadu include monitoring of dissolved silica levels in surface waters along the course of the Cauvery river and results indicated no major changes in the dissolved silica and main solutes over last 30 years (Meunier et al. 2015). Surface water samples collected along the course of the river in Karnataka showed concentrations of chromium, manganese, nickel and lead above the maximum permissible limits and copper and zinc within the limits of Bureau of Indian Standards (BIS) for drinking water quality (Begum et al. 2009). Surface waters of river Cauvery in Tamil Nadu tested in 2010 revealed concentrations of cadmium, chromium, copper, iron, nickel, lead, zinc and mercury within the prescribed limits (Krishnamoorthy and Nagarajan 2013). Heavy metals in the surface sediments of the Cauvery delta have been studied earlier (Dhanakumar et al. 2013). Suitability of groundwater for drinking and domestic use based on major ions (Vetrimurugan and Elango 2015) and the sources of groundwater contamination were also reported (Vetrimurugan et al. 2013). However, no studies have reported the presence of heavy metals in groundwater of this area (Fig. 1). The aim of the present study was to assess the health risk to humans due to drinking groundwater containing heavy metals with the help of heavy metal pollution index (HPI) and statistical tools. Realising the importance of the presence of heavy metals in groundwater used for drinking purpose and the impact it will have on human health, such a study will be of immense use.

\section{Description of study area}

This area covers about $168 \mathrm{~km}^{2}$ (Fig. 1) and experiences humid and tropical climate. Temperature ranges between 31.8 and $21.7^{\circ} \mathrm{C}$ and relative humidity is high $(70 \%)$ during August to April, and minimum humidity varies from 60 to $65 \%$ between June and July. Average annual rainfall in this region is $1200 \mathrm{~mm}$ which is largely contributed by northeast monsoon $(70 \%)$ and to lesser extent by southwest monsoon $(20 \%)$. This region is a monotonous pediplain with maximum elevation of $8 \mathrm{~m}$ amsl. Aeolian action is evident in the coastal tract that resulted in the formation of sand dunes. Being sited on sea coast, coastal geomorphological units like sand dunes, tidal inlet, spit and bars are common. Situated on the tail end portion of the Cauvery delta, five distributaries are draining the region and these river channels slope by about $1 \%$.

Geologically this region is covered by a thick Quaternary and recent alluvial deposits comprising of yellow coloured sand and hard plastic brown clay. Thickness of the alluvium ranges from 30 to $60 \mathrm{~m}$ which is underlain by the Karaikal beds of Pliocene age. This formation that varies in thickness from 100 to $150 \mathrm{~m}$ is underlain by the Cuddalore sandstone of Miocene age which is composed of highly porous sandstone with intercalation of clay beds. This region is intensively irrigated and the main crops grown are paddy and pulses. Minor crops include groundnut, cotton, sugarcane, coconut, flowers and vegetables. Agriculture was largely dependent on the 

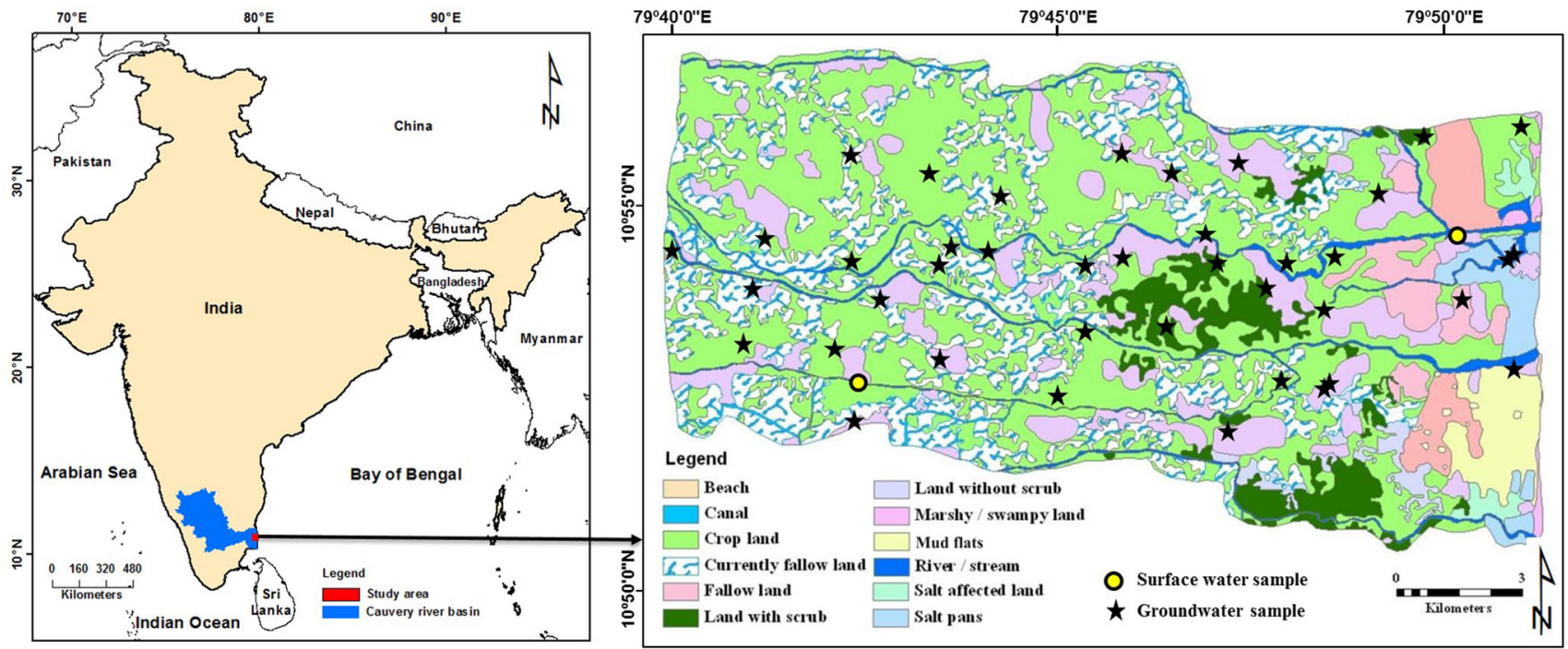

Fig. 1 Location and land use of study area with monitoring locations

availability of water in the river channels but in recent years it is hampered mostly because of non-availability of surface water due to damming, poor storage in the reservoirs and also due to frequent failure of monsoons (Vetrimurugan et al. 2013). This area also hosts a number of paint, fertilizers, electroplating, mineral, metal and sugar industries. Large part of the water requirements in this area for both agriculture and industries is met by groundwater. As groundwater has been used for domestic and drinking purposes in this region, it is essential to determine its chemical composition at regular intervals.

\section{Sampling and data analysis}

Groundwater samples were collected from 40 locations (Fig. 1) in the Cauvery river basin during January 2015. Two surface water samples were also collected from the rivers. Electrical conductivity (EC) was measured in the water samples in the field using portable meter (Eutech model: Testr 35) which was pre-calibrated using 84 and $1413 \mu \mathrm{S} / \mathrm{cm}$ conductivity solutions. Total dissolved solids (TDS) in the samples were calculated using: TDS $(\mathrm{mg} / \mathrm{l})=$ EC $(\mu \mathrm{S} / \mathrm{cm}) \times 0.64$ (Lloyd and Heathcote 1985). Water samples were collected in pre-cleaned bottles of $100 \mathrm{ml}$ capacity and acidified with nitric acid. These samples were analysed for 16 heavy metals: silver (Ag), aluminium ( $\mathrm{Al})$, boron $(\mathrm{B})$, cadmium $(\mathrm{Cd})$, chromium $(\mathrm{Cr})$, copper $(\mathrm{Cu})$, iron $(\mathrm{Fe})$, manganese $(\mathrm{Mn})$, nickel $(\mathrm{Ni})$, lead $(\mathrm{Pb})$, zinc $(\mathrm{Zn})$, cobalt $(\mathrm{Co})$, lithium $(\mathrm{Li})$, silicon $(\mathrm{Si})$, zirconium $(\mathrm{Zr})$ and titanium (Ti) using inductively coupled plasma mass spectrometry. Blanks and standards were run at regular intervals and for every 10 samples, one sample was analysed in triplicate to ensure accuracy and consistency of the results.

\section{Heavy metal pollution index}

Permissible limits for drinking water given by various organisations and countries ascertain the suitability of water based on each metal; however, a cumulative understanding of the pollution level based on all heavy metals is not achieved. Hence many researchers have used HPI as a comprehensive tool to determine the overall quality of water based on heavy metals (Horton 1965; Brown et al. 1970). Weights of each metal are assigned between 0 and 1 which depends on the relative importance of the metal that builds on the standard permissible limit for the metal in drinking water.

HPI based on the 16 heavy metals is calculated by,

HPI $=\frac{\sum_{i=1}^{n} W_{\mathrm{i}} Q_{\mathrm{i}}}{\sum_{i=1}^{n} W_{\mathrm{i}}}$

where $W_{\mathrm{i}}$ is the unit weightage of the ' $\mathrm{i}$ ' th heavy metal, $n$ is the number of heavy metal considered and $Q \mathrm{i}$ is the subindex of the ' $i$ 'th heavy metal.

The unit weight, $W_{\mathrm{i}}$, is calculated by,

$W_{\mathrm{i}}=K / S_{\mathrm{i}}$

where $K$ is the proportionality constant, $S_{\mathrm{i}}$ is the standard permissible limit in water for the ' $i$ ' th heavy metal.

The proportionality constant, $K$ is calculated by,

$\mathrm{K}=1 / \sum_{i=1}^{n} \frac{1}{S_{\mathrm{i}}}$

$\sum_{i=1}^{n} \frac{1}{S_{\mathrm{i}}}=\frac{1}{S_{1}}+\frac{1}{\mathrm{~S}_{2}}+\frac{1}{S_{3}} \cdots+\frac{1}{S_{i}}$

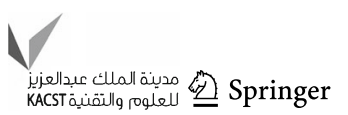


where $S_{1}, S_{2}, S_{3}$, etc. represent standards for different heavy metals in water such as silver, arsenic, copper, lead, etc.

The sub-index, $Q_{\mathrm{i}}$, is calculated by,

$Q_{\mathrm{i}}=\sum_{i=1}^{n} \frac{\left|M_{\mathrm{i}}-I_{\mathrm{i}}\right|}{\left(S_{\mathrm{i}}-I_{\mathrm{i}}\right)} \times 100$

where $M_{\mathrm{i}}$ is the monitored value of heavy metal of the ' $i$ 'th heavy metal, $I_{\mathrm{i}}$ is the ideal value of the ' $\mathrm{i}$ 'th heavy metal based on international limits for drinking water and $S_{\mathrm{i}}$ is the standard value of 'i' th heavy metal.

\section{Chemical toxicity}

Human health risk due to ingestion of groundwater with various ions, i.e., non-carcinogenic risk or chemical toxicity was assessed using hazard index (HI) which is based on the following equations (US 1989):

$\mathrm{LADD}=(C \times \mathrm{IR} \times \mathrm{ED} \times \mathrm{EF}) /(\mathrm{BW} \times \mathrm{AT})$

where

LADD is the lifetime average daily dose of ingestion of heavy metal through drinking water $(\mathrm{mg} / \mathrm{kg} / \mathrm{day})$,

$C$ is the concentration of the heavy metal in water $(\mathrm{mg} /$ 1),

IR is the ingestion rate of water $[250 \mathrm{ml} /$ day for infants, i.e., 0 to 12 months, $1.5 \mathrm{l}$ /day for children (Brindha et al. 2016) and 3 1/day (Planning Commission 2011)],

EF is the exposure frequency (days/year),

ED is the exposure duration [66.4 years (UNDESA 2013)],

$\mathrm{BW}$ is the body weight [6.9 $\mathrm{kg}$ for infants, $18.7 \mathrm{~kg}$ for children and $57.5 \mathrm{~kg}$ (ICMR 2009)],

AT is the average time (days).

This equation was modified with the assumption that the water is consumed throughout the year (exposure frequency) for a lifetime (exposure duration) by an individual. In that case the exposure frequency and duration will be equal to the average time and hence the equation is simplified as,

$\mathrm{LADD}=(C \times \mathrm{IR}) /(\mathrm{BW})$

Hazard quotient index (US EPA 1989) is calculated as,

$\mathrm{HQ}=\mathrm{LADD} / \mathrm{RfD}$

where,

HQ is the hazard quotient,

LADD is the lifetime average daily dose of ingestion of heavy metal through drinking water $(\mathrm{mg} / \mathrm{kg} /$ day $)$ calculated by Eq. 7 ,

RfD is the reference dose for a heavy metal that an individual can be exposed to in a day over his/her lifetime
Table 1 Non-carcinogenic effects of metals due to long term exposure and its oral reference doses

\begin{tabular}{lll}
\hline Heavy metal & $\begin{array}{l}\text { Reference dose } \\
(\text { RfD in } \mathrm{mg} / \mathrm{kg} / \mathrm{day})\end{array}$ & References \\
\hline Silver & $5 \times 10^{-3}$ & IRIS from US EPA (2009) \\
Aluminium & Not available & - \\
Boron & $2 \times 10^{-1}$ & IRIS (2011) \\
Cadmium & $5 \times 10^{-4}$ & IRIS from US EPA (2009) \\
Chromium & $3 \times 10^{-3}$ & IRIS from US EPA (2009) \\
$\quad$ (total) & Not available & - \\
Cobalt & $5 \times 10^{-3}$ & US EPA from CHMP (2007) \\
Copper & Not available & - \\
Iron & $1.4 \times 10^{-1}$ & IRIS (2011) \\
Manganese & $2 \times 10^{-2}$ & Kim et al. (2011) \\
Nickel & $3.6 \times 10^{-3}$ & Viridor Waste Ltd (2009) \\
Lead & $2 \times 10^{-2}$ & US EPA (2016) \\
Lithium & Not available & - \\
Silicon & Not available & - \\
Titanium & Not available & - \\
Zirconium & $3 \times 10^{-1}$ & IRIS (2005) \\
Zinc & & \\
\hline
\end{tabular}

without experiencing any deleterious health effect $(\mathrm{mg} /$ $\mathrm{kg} /$ day). The RfD of various metals is given in Table 1 .

The non-carcinogenic risk given by $\mathrm{HI}$ is sum of the HQ of all metals.

$\mathrm{HI}_{i}=\sum \mathrm{HQ}_{i}$

\section{Factor analysis}

Statistical analysis was performed using IBM SPSS (2013). Aiding as a useful tool, factor analysis has been widely adopted to categorise datasets. Eigen values of the factors represent the common variance in the data and the similarity between the variables is given by factor scores. Components with eigen values above 1 are normally considered statistically reasonable for the interpretation. Strong, moderate and weak relationships both positive and negative are displayed by the factor scores that help to categorise the variables, in this case, the heavy metals.

\section{Results and discussion}

General quality of groundwater can be determined by the total ionic composition denoted by EC. Range of EC in groundwater was $476-5330 \mu \mathrm{S} / \mathrm{cm}$ with a mean of $2038 \mu \mathrm{S} / \mathrm{cm}$. EC of the two surface water samples was 502 and $410 \mu \mathrm{S} / \mathrm{cm}$. Table 2 gives the suitability of 
Table 2 Water type and suitability based on EC and TDS

\begin{tabular}{|c|c|c|c|c|}
\hline \multirow[t]{2}{*}{ Parameter } & \multirow[t]{2}{*}{ Classification } & \multirow[t]{2}{*}{ Water type/suitability } & \multicolumn{2}{|c|}{ Number of samples } \\
\hline & & & $\begin{array}{l}\text { Groundwater } \\
(n=40)\end{array}$ & Surface water $(n=2)$ \\
\hline \multirow[t]{4}{*}{$\mathrm{EC}(\mu \mathrm{S} / \mathrm{cm})(\mathrm{WHO} 1993)$} & $<750$ & Desirable & 4 & 2 \\
\hline & $750-1500$ & Permissible & 11 & Nil \\
\hline & $1500-3000$ & Not permissible & 19 & Nil \\
\hline & $>3000$ & Hazardous & 6 & Nil \\
\hline \multirow[t]{4}{*}{ TDS (mg/l) (Freeze and Cherry 1979) } & $<1000$ & Fresh & 16 & 2 \\
\hline & $1000-10,000$ & Brackish & 24 & Nil \\
\hline & $10,000-100,000$ & Saline & Nil & Nil \\
\hline & $>1,00,000$ & Brine & Nil & Nil \\
\hline \multirow[t]{4}{*}{ TDS (mg/l) (Davis and DeWiest 1966) } & $<500$ & Desirable for drinking & 4 & 2 \\
\hline & $500-1000$ & Permissible for drinking & 12 & Nil \\
\hline & $1000-3000$ & Useful for irrigation & 23 & Nil \\
\hline & $>3000$ & Unfit for drinking and irrigation & 1 & Nil \\
\hline
\end{tabular}

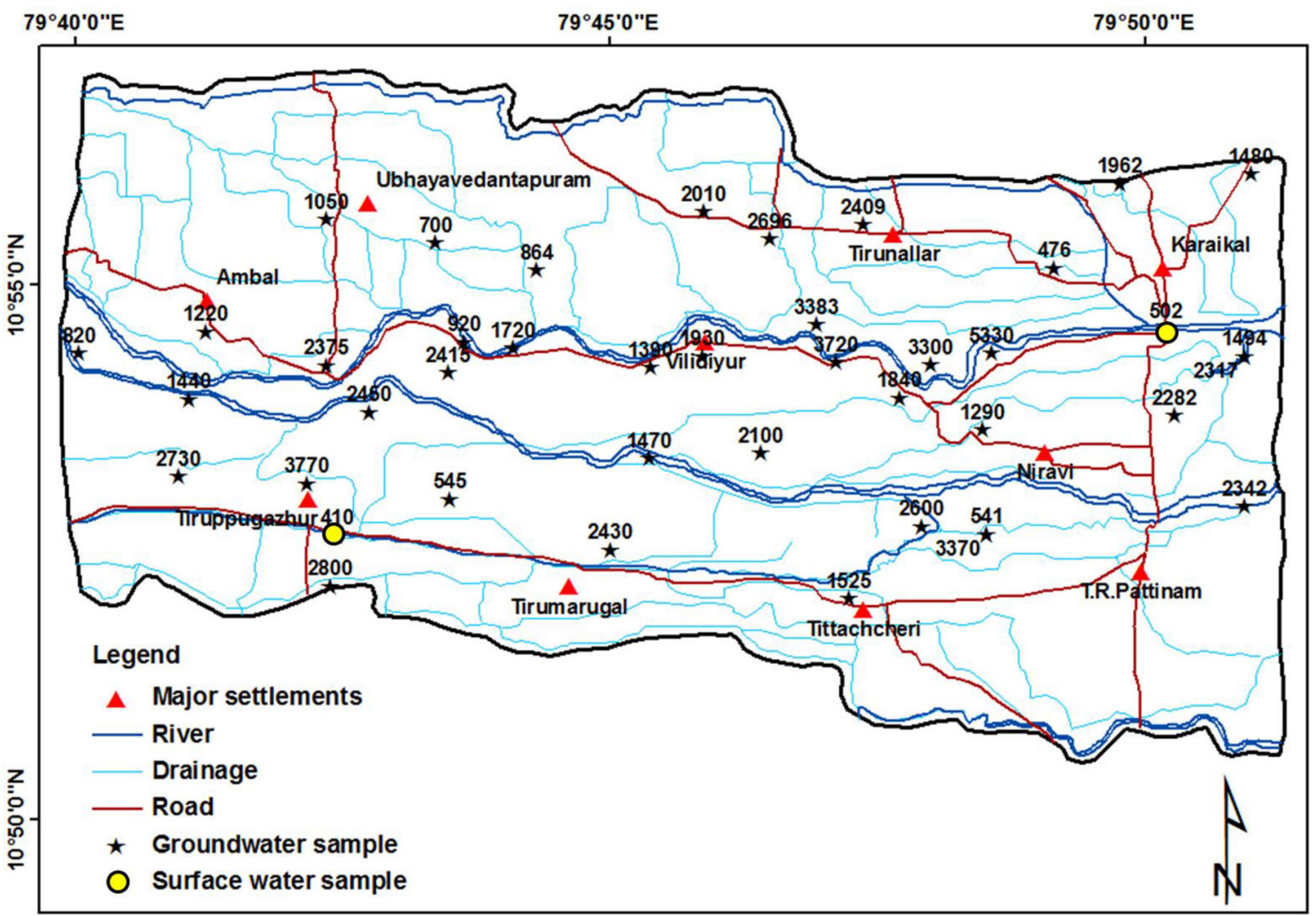

Fig. 2 Spatial variation in EC of groundwater

groundwater and surface water for drinking use. Most of the groundwater samples were not suitable for drinking based on the EC (Table 2). Spatial variation in EC of groundwater is given in Fig. 2. Six locations had EC greater than $3000 \mu \mathrm{S} / \mathrm{cm}$ which is hazardous for ingestion. Earlier study by Vetrimurugan and Elango (2015) reported EC up to $7850 \mu \mathrm{S} / \mathrm{cm}$. Large part of the groundwater samples was useful for irrigation based on TDS (57\%) and groundwater was fresh (40\%) as well as brackish $(60 \%)$ in nature (Table 2). High EC and 
TDS of groundwater make it unsuitable for domestic use and to some extent for irrigation. However, this requires further study on the major ion concentration in groundwater of this region.

Sixteen heavy metals were analysed in groundwater and the order of dominance of these heavy metals was: chromium $<$ zinc $<$ copper $<$ cadmium $<$ cobalt $<$ iron $<$ aluminium $<$ nickel $<$ titanium $<$ zirconium $<$ boron $<$ silver $<$ manganese $<$ lead $<$ lithium $<$ silicon. Statistical summary of heavy metals in groundwater is given in Table 3. Significance of the presence of heavy metals has been considered in framing the criteria for recommended limits in drinking water (BIS 2012; US EPA 2014). Most heavy metals are required within the recommended limits in the human body for the smooth functioning of metabolic activities. Some of the beneficial health effects and negative consequences due to ingestion of heavy metals monitored in this study are compiled from United States Environmental Protection Agency (US EPA 2014) and Agency for Toxic Substances and Disease Registry (ATSDR 2014). Chromium is a widely reported pollutant around tanning industries (Brindha and Elango 2012) and known to cause allergic dermatitis. But, chromium (III) is required by the human body for insulin secretion that helps to maintain normal glucose metabolism in the human body. Though cadmium is not yet proved to be either biologically essential or beneficial, it is suspected to cause renal arterial hypertension. At higher levels, cadmium and hexavalent chromium can affect the liver and kidney severely. Oral exposure to aluminium can also affect the kidneys apart from causing bone and brain diseases at high levels. Boron is an essential substance for plant growth but in higher concentrations can be toxic. Exposure to high amounts over short period of time can affect stomach, intestines, liver, kidney and brain. Copper is essential for the human body and its deficiency results in nutritional anaemia as it helps to produce red blood cells and strengthen the immune system; moderate levels can cause gastrointestinal distress and large amounts are toxic and may severely affect the liver (US EPA 1994). Lead, a highly toxic heavy metal even in small concentrations, delays physical and mental development in infants and causes kidney problems and high blood pressure in adults (US EPA 2014). Ill effects of zinc are not clearly known, but, it is essential to perform normal metabolic activities, and deficiency in children will retard growth and may decrease general body resistance to disease. Zinc and lead also result in drinking water through corrosion of household plumbing system. Iron, an essential component of haemoglobin (red blood cells) and myoglobin (muscle cells) play a major role in carrying oxygen from lungs to the tissues, while benefits of manganese include healthy bones. Use of iron is disagreeable in food and beverage processing and additionally causes stains in laundry and utensils (US EPA 1994). Black stains on porcelain, enamel, and fabrics are also caused by manganese. Iron and

Table 3 Statistical summary of metal concentrations in groundwater

\begin{tabular}{|c|c|c|c|c|c|c|}
\hline $\begin{array}{l}\text { Heavy } \\
\text { metal }\end{array}$ & $\begin{array}{l}\text { Minimum } \\
(\mathrm{mg} / \mathrm{l})\end{array}$ & $\begin{array}{l}\text { Maximum } \\
(\mathrm{mg} / \mathrm{l})\end{array}$ & $\begin{array}{l}\text { Mean } \\
(\mathrm{mg} / \mathrm{l})\end{array}$ & $\begin{array}{l}\text { Standard } \\
\text { deviation }\end{array}$ & $\begin{array}{l}\text { Desirable } \\
\text { limit }(\mathrm{mg} / \mathrm{l}) \\
\text { (BIS 2012) }\end{array}$ & $\begin{array}{l}\text { Permissible limit in the absence } \\
\text { of alternate source (mg/l) } \\
\text { (BIS 2012) }\end{array}$ \\
\hline $\mathrm{Ag}$ & 0.25 & 0.32 & 0.28 & 0.03 & 0.1 & No relaxation \\
\hline $\mathrm{Al}$ & BDL & 0.33 & 0.10 & 0.12 & 0.03 & 0.2 \\
\hline B & BDL & 1.00 & 0.25 & 0.21 & 0.5 & 1 \\
\hline $\mathrm{Cd}$ & BDL & 0.06 & 0.00 & 0.01 & 0.003 & No relaxation \\
\hline $\mathrm{Cr}$ & BDL & 0.02 & 0.00 & 0.00 & 0.05 & No relaxation \\
\hline $\mathrm{Cu}$ & BDL & 0.05 & 0.00 & 0.01 & 0.05 & 15 \\
\hline $\mathrm{Fe}$ & 0.05 & 0.55 & 0.08 & 0.08 & 0.3 & No relaxation \\
\hline $\mathrm{Mn}$ & 0.01 & 7.00 & 0.31 & 1.12 & 0.1 & 0.3 \\
\hline $\mathrm{Ni}$ & 0.09 & 0.17 & 0.12 & 0.02 & 0.02 & No relaxation \\
\hline $\mathrm{Pb}$ & 0.19 & 0.66 & 0.38 & 0.10 & 0.01 & No relaxation \\
\hline $\mathrm{Zn}$ & BDL & 0.03 & 0.00 & 0.01 & 5 & 15 \\
\hline Co & BDL & 0.06 & 0.03 & 0.02 & Unavailable & Unavailable \\
\hline $\mathrm{Li}$ & 0.27 & 1.42 & 0.95 & 0.53 & Unavailable & Unavailable \\
\hline $\mathrm{Si}$ & BDL & 26.48 & 9.82 & 7.01 & Unavailable & Unavailable \\
\hline $\mathrm{Zr}$ & BDL & 0.34 & 0.14 & 0.16 & Unavailable & Unavailable \\
\hline $\mathrm{Ti}$ & BDL & 0.32 & 0.14 & 0.15 & Unavailable & Unavailable \\
\hline
\end{tabular}


manganese can promote growth of certain bacteria that can clog pipes and wells. Negative effects of nickel in humans are believed to be minimal but maybe toxic to certain flora and fauna. Small concentrations of lithium are beneficial that it strengthens the cell wall and improves disease resistance. Silver is toxic in large concentrations and can affect eyes and skin. Occupational exposure to cobalt and tungsten carbide simultaneously has shown risk of lung cancer but there is insignificant evidence to support the case. Beneficial effect of cobalt is that it has been used to treat anaemia as it increases red blood cell production. Silicon, the second most abundant element in the earth's crust next only to oxygen is known to have potential therapeutic effects. Zirconium and titanium are also known to be toxic at higher levels, but, most of this is due to occupational exposure rather than from drinking water.

Desirable and highest permissible limits for 11 of the 16 heavy metals studied have been proposed by BIS except for cobalt, lithium, silicon, titanium and zirconium. World Health Organization (WHO 2011), US EPA (2014) and Health Canada (2006) also did not propose limits to these metals, and hence these five metals could not be included in checking the groundwater suitability for drinking. Comparing the heavy metals' concentration recorded at different sampling locations with the standards of BIS (2012) shows that chromium and zinc were within the limits and do not pose any hazard. Silver, lead and nickel were above limits in all groundwater samples. Aluminium, boron, cadmium, copper, iron and manganese exceeded limits in $45,10,50,2.5,2.5$ and $22.5 \%$ of the samples, respectively. Heavy metals that show spatial variation in the concentration, i.e., desirable and undesirable locations for using groundwater for drinking are given in Fig. 3. To represent the overall quality of groundwater, HPI based on 11 metals was calculated using the values in Table 4. HPI of groundwater ranges from 47 to 104 for groundwater, and for the surface water samples, 50 and 51 (Fig. 4). HPI is usually classified into five categories, i.e., excellent (0-25), good (26-50), poor (51-75), very poor (76-100) and unsuitable $(>100)$. Spatial variation in concentration of heavy metals and HPI shows contamination more in the northern and eastern parts in the agricultural areas (Fig. 4).

\section{Human exposure risk}

Though comparing the determined concentration of an ion in groundwater used for drinking with the national and international standards ascertains their suitability for drinking, sometimes this alone does not stand sufficient to establish the risk of drinking groundwater as the quantity of water consumed by humans is not fully taken into account. At such times, human exposure, i.e., any condition which provides an opportunity for an external environmental agent to enter the body, in this case, through the drinking water pathway could be used to determine the risk. As an extreme case, the exposure pathway to these ions in groundwater through the drinking water pathway was calculated considering that groundwater is used by the entire population for drinking purposes. This will determine if groundwater in this area can serve as a source of drinking water in the absence of an alternate source and the effects on human health that it might bring. The non-carcinogenic risk given by $\mathrm{HI}$ was calculated for ten heavy metals for which RfD values were available. If the $\mathrm{HI} \leq 1$, it is safe and a HI $\geq 1$ may present a risk. This is applicable for one heavy metal or for many metals as a whole. HI indicates that the entire area has non-carcinogenic risk due to consumption of groundwater (Table 5). Minimum HI was 5, 11 and $24 \mathrm{mg} / \mathrm{kg} /$ day for infants, children and adults, respectively. Potential risks due to silver, lead, lithium, cadmium and manganese were more, and these ions contribute to a larger percentage in the HI. Spatial variations in the $\mathrm{HI}$ at different age groups are given in Fig. 5.

\section{Sources of heavy metals}

Understanding the sources of these heavy metals in groundwater will help to prevent groundwater contamination in future. Commonly, groundwater contamination can be classified as natural and anthropogenic. Independent as well as multiple sources contributing to the occurrence of certain ions together in groundwater can be identified with factor analysis. Identification of factors is based on dominant factor loadings obtained for heavy metals in each factor. In this study, four factors appeared having a cumulative variance of $82 \%$ (Table 6). These four factors exhibit eigen values above 1 and hence are considered for further reasoning as they are considered statistically significant.

Factor 1 represents the highest variance of $34 \%$ and expressed strong positive loadings between silver, cobalt, zirconium and titanium and moderate correlation with aluminium. A strong negative loading was shown by lithium which means that the source of lithium does not contribute to the other five heavy metals. Being located near the coast the study area experiences groundwater contamination due to seawater intrusion (Vetrimurugan et al. 2013) to some extent. Lithium is one of the heavy metals in seawater that is considered as an indicator for saline intrusion (Martos et al. 1999) along with bromide, chloride and EC. Other heavy metals showing positive relationship are present in very low concentration in

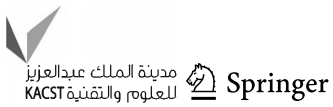




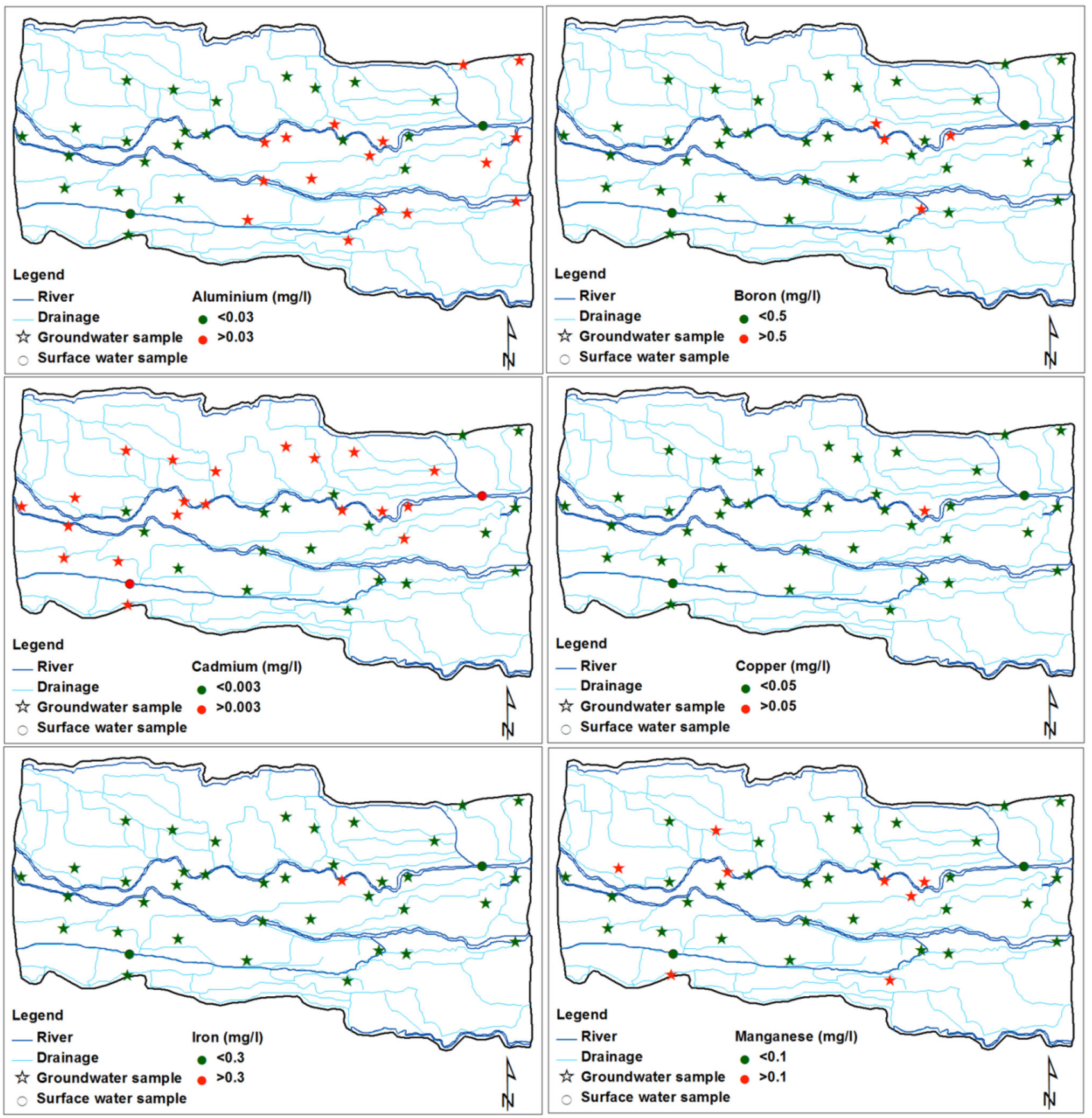

Fig. 3 Spatial variation in few heavy metal concentrations in groundwater

seawater when compared to lithium (Turekian 1968) which indicates that this factor is not due to seawater intrusion. Heavy metals like silver, cobalt, zirconium and titanium are possibly due to the runoff and discharge of wastewater from industrial areas on the banks of the river.

Factor analysis reveals that cadmium, copper and chromium show strong positive relationship in factor 2 and moderate loadings by two metals (nickel and lead).
Fertilizers in agricultural areas are a major external source for cadmium (Nouri et al. 2008; Shan et al. 2013). Other metals in factor 2 that show positive relation with cadmium may also be much influenced by agrochemicals. Phosphate fertilizers contain heavy metals in small quantities and long term use of these fertilizers has been reported to cause groundwater contamination in cultivated areas (Nouri et al. 2008; Sabiha-Javied et al. 2009). This factor thus attributes 
Table 4 Limits and weight of heavy metals used for HPI calculation Heavy metal Standard limit (mg/l) Ideal value (mg/l) Weight (Wi)

\begin{tabular}{llll}
\hline Silver & 0.1 & 0 & $1.9 \times 10^{-4}$ \\
Aluminium & 0.2 & 0.03 & $3.8 \times 10^{-4}$ \\
Boron & 1 & 0.5 & $1.9 \times 10^{-3}$ \\
Cadmium & 0.003 & 0 & $5.7 \times 10^{-6}$ \\
Chromium & 0.05 & 0 & $9.5 \times 10^{-5}$ \\
Copper & 1.5 & 0.05 & $2.8 \times 10^{-3}$ \\
Iron & 0.3 & 0 & $5.7 \times 10^{-4}$ \\
Manganese & 0.3 & 0.1 & $5.7 \times 10^{-4}$ \\
Nickel & 0.02 & 0 & $3.8 \times 10^{-5}$ \\
Lead & 0.01 & 0 & $1.9 \times 10^{-5}$ \\
Zinc & 15 & 5 & $2.8 \times 10^{-2}$ \\
\hline
\end{tabular}

to application of fertilizers and other agrochemicals during farming activities.

High correlation between iron and zinc is seen as factor 3 in this area. Iron occurs commonly in a variety of rock forming minerals (Spurgeon et al. 2008). Zinc coexists with iron as it is known to exhibit similar geochemical affinities (Alloway 1995). This correlation may therefore be associated to natural factors, i.e., weathering of local rocks and associated processes. Factor 4 represents silicon as an independent ion that does not correlate with any other heavy metals. Silicate minerals make up to $60 \%$ of the earth's crust and hence silica, the natural form of silicon is found in almost all rocks, soil and clays (Iler 1955; Nebergall et al. 1963). Another possible source for this heavy metal in a coastal area can be seawater intrusion as seawater contains silicon up to $2.9 \mathrm{mg} / \mathrm{l}$ (Turekian 1968). Boron indicating moderate loadings is also present in seawater at significant levels $(4.45 \mathrm{mg} / \mathrm{l})$ (Turekian 1968) confirming that saline intrusion can be a trivial reason for this factor. Apart from these two metals, lead shows moderate correlation, but exists in seawater at very trace levels. Lead also exhibits correlation with other metals in factor 2 where the major source is fertilizer application. This relates as a better reason for lead in groundwater other than seawater. Thus, this factor represents a mixture of sources largely by saline water intrusion and to some extent by lithogenic sources. Of the 16 heavy metals, manganese did not show strong affinity with any of the metals, but, exhibits weak correlation under factor 1 implying the source of this could also be considered wastewater from industries.

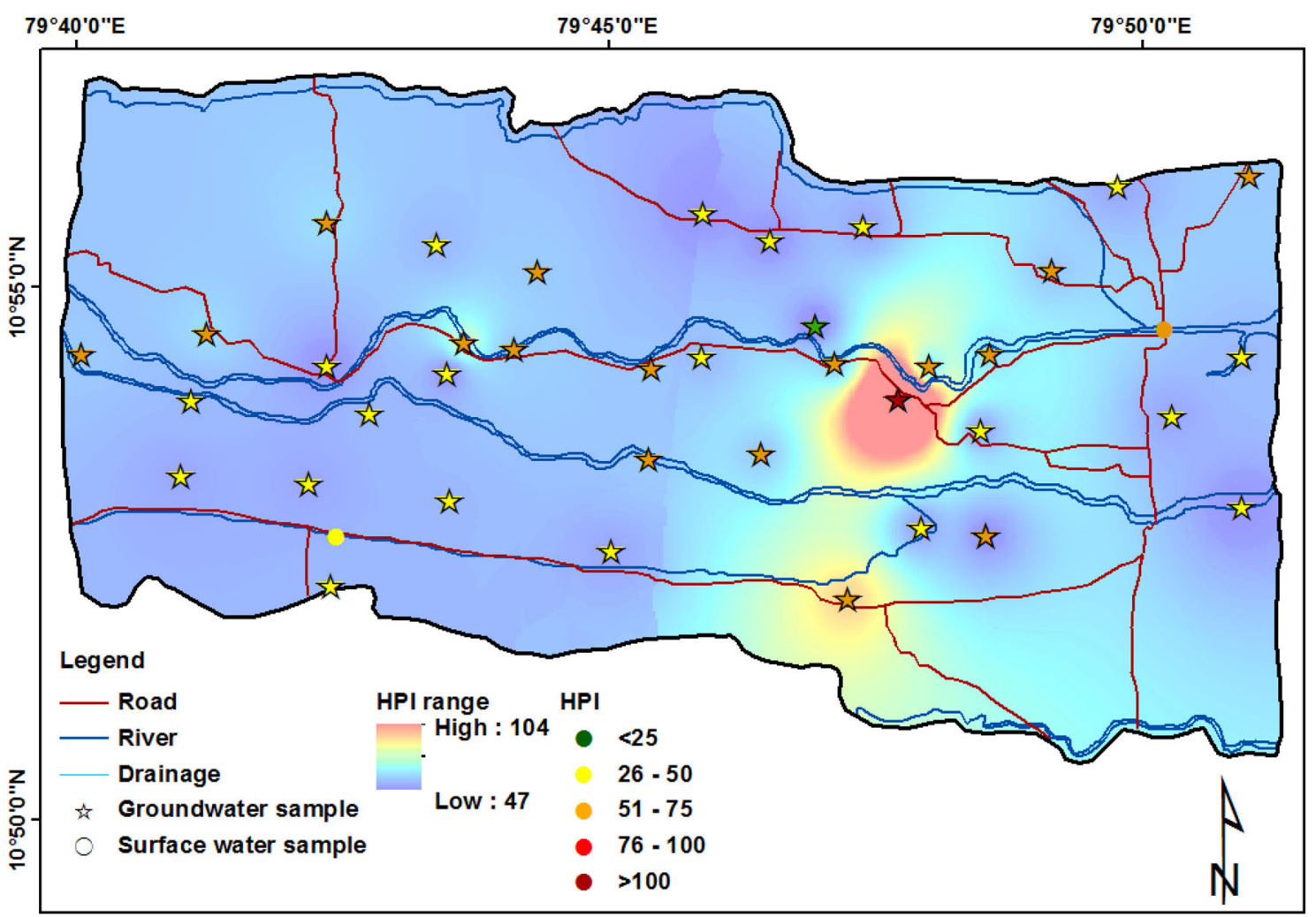

Fig. 4 Spatial variation in HPI of groundwater 
Table 5 Non-carcinogenic risk ( $\mathrm{mg} / \mathrm{kg} /$ day) associated with groundwater used for drinking

\begin{tabular}{|c|c|c|c|c|c|c|c|c|c|c|c|c|c|c|c|}
\hline \multirow[t]{2}{*}{ Heavy metal } & \multicolumn{5}{|c|}{ Infants } & \multicolumn{5}{|c|}{ Children } & \multicolumn{5}{|c|}{ Adults } \\
\hline & Min & Max & Mean & Median & SD & Min & Max & Mean & Median & SD & Min & Max & Mean & Median & SD \\
\hline Silver & 1.8 & 2.3 & 2.0 & 1.9 & 0.2 & 3.9 & 5.1 & 4.4 & 4.1 & 0.5 & 2.6 & 3.3 & 2.9 & 2.7 & 0.3 \\
\hline Boron & 0.0 & 0.2 & 0.0 & 0.0 & 0.0 & 0.0 & 0.4 & 0.1 & 0.1 & 0.1 & 0.0 & 0.3 & 0.1 & 0.1 & 0.1 \\
\hline Cadmium & 0.0 & 4.4 & 0.4 & 0.2 & 0.7 & 0.0 & 9.8 & 0.8 & 0.5 & 1.6 & 0.0 & 6.4 & 0.5 & 0.3 & 1.0 \\
\hline Chromium & 0.0 & 0.3 & 0.0 & 0.0 & 0.0 & 0.0 & 0.6 & 0.0 & 0.0 & 0.1 & 0.0 & 0.4 & 0.0 & 0.0 & 0.1 \\
\hline Copper & 0.0 & 0.4 & 0.0 & 0.0 & 0.1 & 0.0 & 0.9 & 0.0 & 0.0 & 0.1 & 0.0 & 0.6 & 0.0 & 0.0 & 0.1 \\
\hline Manganese & 0.0 & 1.8 & 0.1 & 0.0 & 0.3 & 0.0 & 4.0 & 0.2 & 0.0 & 0.6 & 0.0 & 2.6 & 0.1 & 0.0 & 0.4 \\
\hline Nickel & 0.2 & 0.3 & 0.2 & 0.2 & 0.0 & 0.4 & 0.7 & 0.5 & 0.5 & 0.1 & 0.2 & 0.5 & 0.3 & 0.3 & 0.0 \\
\hline Lead & 1.9 & 6.6 & 3.8 & 4.0 & 1.0 & 4.2 & 14.6 & 8.5 & 8.8 & 2.3 & 2.7 & 9.5 & 5.5 & 5.7 & 1.5 \\
\hline Zinc & 0.0 & 0.0 & 0.0 & 0.0 & 0.0 & 0.0 & 0.0 & 0.0 & 0.0 & 0.0 & 0.0 & 0.0 & 0.0 & 0.0 & 0.0 \\
\hline Lithium & 0.5 & 2.6 & 1.7 & 2.5 & 0.9 & 1.1 & 5.7 & 3.8 & 5.6 & 2.1 & 0.7 & 3.7 & 2.5 & 3.6 & 1.4 \\
\hline HI & 5.1 & 16.7 & 8.3 & 8.3 & 1.8 & 11.4 & 37.0 & 18.3 & 18.4 & 4.0 & 7.4 & 24.1 & 11.9 & 11.9 & 2.6 \\
\hline
\end{tabular}

Surface water pollution of heavy metals due to disposal of industrial wastes in the Cauvery river has been reported earlier (Begum et al. 2009; INSA 2011; Krishnamoorthy and Nagarajan 2013). Groundwater in this part of the Cauvery river basin is polluted with silver, lead and nickel in all the sampling locations and parts of the area are polluted with aluminium, boron, cadmium, copper, iron and manganese. It is important that the groundwater from this region should not be used for drinking purpose without treatment. Major cause for pollution is due to the indiscriminate disposal of effluents into the river by several industries, including paper, sugar, textile, cement, electroplating, paint, mineral and metal. Hence, groundwater pollution can be prevented only by cleaning up of the river and by preventing the future release of effluents from industries. Pollution due to seawater intrusion is also a threat in this area which should be regulated by controlled pumping and conjunctive use of surface and groundwater to avoid salinization. Groundwater monitoring and management is essential considering the prevailing local conditions, i.e., use of groundwater as a source for drinking, domestic, irrigation needs, etc. and occurrence of multiple pollutants.

\section{Conclusion}

Heavy metal contamination in a part of the Cauvery river basin, Tamil Nadu, India, was studied as it is an intensively irrigated area. Order of dominance of heavy metals in groundwater was silicon $>$ lithium $>$ lead $>$ manganese $>$ silver $>$ boron $>$ zirconium $>$ titanium $>$ nickel $>$ aluminium $>$ iron $>$ cobalt $>$ cadmium $>$ copper $>$ zinc $>$ chromium. Except for chromium and zinc, high levels of silver, lead, nickel, aluminium, boron, cadmium, copper, iron and manganese were determined in the study area. HPI calculated based on 11 heavy metals was from 47 to 104, and for the two surface water samples, 50 and 51. Most of the area had poor-to-unsuitable water quality. Human exposure risk calculated based on chemical toxicity for using groundwater as drinking source was high due to silver, lead, manganese, cadmium and lithium. Cumulative HI was at a maximum of 17,37 and $24 \mathrm{mg} / \mathrm{kg} /$ day for infants, children and adults, respectively. EC was higher at many locations indicating that pollution due to major ions is possible which should also be monitored at regular intervals. Reasons responsible for the co-occurrence of multi-elements in groundwater determined through factor analysis include 
Fig. 5 Variation in hazard index $(\mathrm{mg} / \mathrm{kg} / \mathrm{day})$ due to drinking groundwater
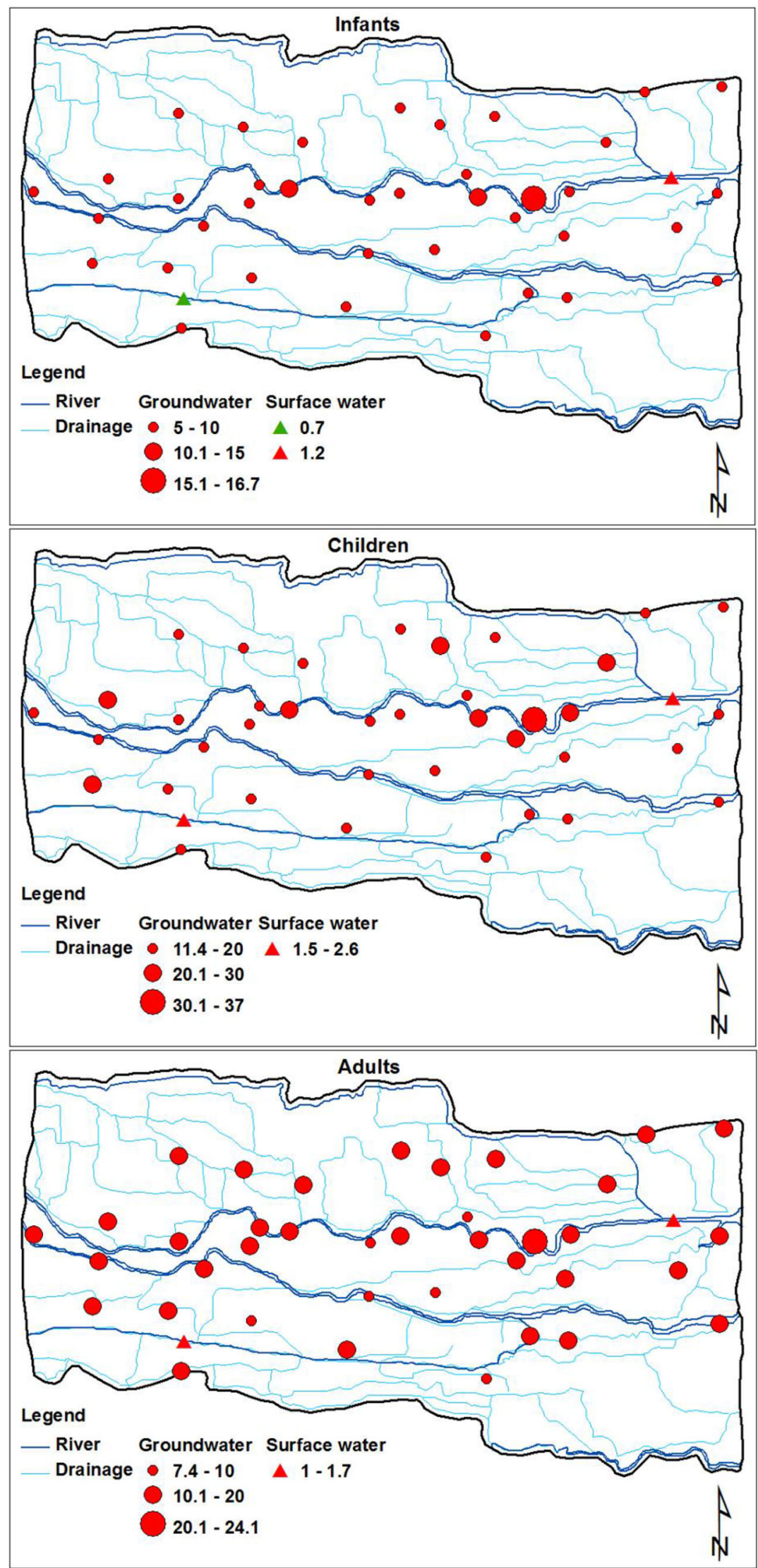

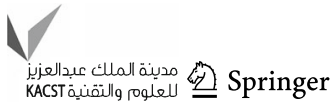


Table 6 Factor analysis of heavy metals in groundwater

\begin{tabular}{lrrrr}
\hline Heavy metals & Factor 1 & Factor 2 & Factor 3 & -0.06 \\
\hline $\mathrm{Ag}$ & 0.98 & 0.08 & -0.11 & -0.08 \\
$\mathrm{Al}$ & 0.59 & -0.05 & 0.35 & -0.19 \\
$\mathrm{~B}$ & 0.35 & 0.33 & -0.14 & -0.47 \\
$\mathrm{Cd}$ & -0.42 & 0.87 & -0.16 & -0.03 \\
$\mathrm{Cr}$ & -0.13 & 0.94 & -0.18 & -0.09 \\
$\mathrm{Cu}$ & -0.06 & 0.93 & 0.95 & -0.06 \\
$\mathrm{Fe}$ & -0.13 & 0.19 & 0.01 & -0.10 \\
$\mathrm{Mn}$ & 0.21 & 0.10 & -0.11 & 0.18 \\
$\mathrm{Ni}$ & -0.02 & 0.70 & 0.26 & -0.16 \\
$\mathrm{~Pb}$ & 0.30 & 0.58 & 0.96 & -0.11 \\
$\mathrm{Zn}$ & -0.08 & 0.09 & 0.41 \\
$\mathrm{Co}$ & 0.89 & 0.32 & -0.08 \\
$\mathrm{Li}$ & -0.98 & 0.02 & -0.06 \\
$\mathrm{Si}$ & 0.18 & -0.11 & 0.21 & 0.09 \\
$\mathrm{Zr}$ & 0.98 & -0.01 & 0.11 & -0.10 \\
$\mathrm{Ti}$ & 0.98 & -0.01 & 0.12 &
\end{tabular}

the natural geogenic processes and anthropogenic inputs such as fertilizer application in farming activities, effluent from industries as well as seawater intrusion. Continuous monitoring of water quality in this region is essential to keep the heavy metal pollution in check, and groundwater should be avoided for drinking due to potential chemical toxicity risk to humans. This study reports for the first time the occurrence of a large number of heavy metals in groundwater of this region and demonstrates the use of HPI and $\mathrm{HI}$ indices to determine the water quality.

Acknowledgments This research work was funded by the Department of Science and Technology, Ministry of Science and Technology, India (Grant SR/S4/ES-21/Cauvery/P6).

Open Access This article is distributed under the terms of the Creative Commons Attribution 4.0 International License (http:// creativecommons.org/licenses/by/4.0/), which permits unrestricted use, distribution, and reproduction in any medium, provided you give appropriate credit to the original author(s) and the source, provide a link to the Creative Commons license, and indicate if changes were made.

\section{References}

Al-Hobaib AS, Al-Jaseem QKh, Baioumy HM, Ahmed AH (2013) Heavy metals concentrations and usability of groundwater at Mahd Adh Dhahab gold mine, Saudi Arabia. Arab J Geosci 6(1):259-270
Alloway BJ (1995) Heavy metals in soils. Chapman and Hall, London Ashraf S, Abbas F, Ibrahim M, Rashid U, Khalid S, Ahmad HR, Hakeem KR, Majeed T (2015) Application of GIS for the identification and demarcation of selective heavy metal concentrations in the urban groundwater. J Geog Sci 25(2):225-235

ATSDR (Agency for Toxic Substances and Disease Registry) (2014) ATSDR Toxic Substances Portal. Available from: http://www. atsdr.cdc.gov/substances/index.asp. Accessed on 23 July 2016

Bakis R, Tuncan A (2011) An investigation of heavy metal and migration through groundwater from the landfill area of Eskisehir in Turkey. Environ Monit Assess 176(1):87-98

Begum A, Ramaiah M, Harikrishna Khan I, Veena K (2009) Heavy metal pollution and chemical profile of Cauvery river water. $\mathrm{E} \mathrm{J}$ Chem 6(1):47-52

Bird G, Macklin MG, Brewer PA, Zaharia S, Balteanu D, Driga B, Serban M (2009) Heavy metals in potable groundwater of mining-affected river catchments, northwestern Romania. Environ Geochem Health 31(6):741-758

BIS (Bureau of Indian Standards) (2012) Indian standard for drinking water-specification, second edition, IS 10500: 2012, Drinking Water Sectional Committee, FAD 25. New Delhi, India

Brindha K, Elango L (2012) Impact of tanning industries on groundwater quality near a metropolitan city in India. Water Resour Manage 26(6): 1747-1761

Brindha K, Elango L (2013) Occurrence of uranium in groundwater of a shallow granitic aquifer and its suitability for domestic use in southern India. J Radioanal Nucl Chem 295:357-367

Brindha K, Elango L (2014) Assessment of heavy metals in top soil around a proposed uranium tailings pond in Southern India. Asian J Water Environ Pollut 11(2):13-17

Brindha K, Vaman KVN, Srinivasan K, Sathis Babu M, Elango L (2014) Identification of surface water-groundwater interaction by hydrogeochemical indicators and assessing the suitability for drinking and irrigational purposes in Chennai, southern India. Appl Water Sci 4(2):159-174 
Brindha K, Jagadeshan G, Kalpana L, Elango L (2016) Fluoride in weathered rock aquifers of southern India: managed Aquifer recharge for mitigation. Environ Sci Pollut Res 23:8302-8316

Brown RM, McClelland NI, Deininger RA, Tozer RG (1970) A water quality index — do we dare? Water Sew Works 117(10):339-343

Chabukdhara M, Nema AK (2012) Assessment of heavy metal contamination in Hindon River sediments: a chemometric and geochemical approach. Chemosphere 87(8):945-953

Davis SN, DeWiest RJM (1966) Hydrogeology. Wiley, New York

Dhanakumar S, Murthy KR, Solaraj G, Mohanraj R (2013) Heavymetal fractionation in surface sediments of the Cauvery river Estuarine region, Southeastern Coast of India. Arch Environ Contam Toxicol 65:14-23

Fendorf S, Michael HA, van Geen A (2010) Spatial and temporal variations of groundwater arsenic in South and Southeast Asia. Science 328(5982):1123-1127

Freeze RA, Cherry JA (1979) Groundwater. Prentice Hall Inc, New Jersey

Fu S, Wei CY (2013) Multivariate and spatial analysis of heavy metal sources and variations in a large old antimony mine, China. J Soils Sediments 13(1):106-116

Giri S, Singh G, Gupta SK, Jha VN, Tripathi RM (2010) An evaluation of metal contamination in surface and groundwater around a proposed uranium mining site, Jharkhand, India. Mine Water Environ 29:225-234

Health Canada (2006) Canadian or BC Health Act Safe Drinking Water Regulation BC Reg 230/92, \& 390 Sch 120, 2001. Task Force of Canadian Council of Resource \& Envir. Ministers Guidelines for Canadian Drinking Water Quality, 1996. Amend

Horton RK (1965) An index number system for rating water quality. J Water Pollut Control Fed 37(3):300-306

IBM SPSS (International Business Machines Corporation Statistical Package for the Social Sciences) (2013) IBM SPSS Statistics for Windows, Version 22.0. IBM Corp, Armonk

ICMR (Indian Council of Medical Research) (2009) Nutrient requirements and recommended dietary allowances for Indians. A report of the expert group of the ICMR, Hyderabad, India, p 334

Iler RK (1955) The colloidal chemistry of silica and silicates. Cornell University Press, Ithaca, New York, p 324

INSA (Indian National Science Academy) (2011) Hazardous metals and minerals pollution in India: sources, toxicity and management- a position paper. Available from: http://citeseerx.ist.psu. edu/viewdoc/download?doi=10.1.1.458.8609\&rep=rep1\&type= pdf. Accessed on 23 July 2016, p 24

IRIS (Integrated Risk Information System) (2005) Zinc and Compounds (CASRN 7440-66-6). Available from: https://cfpub.epa. gov/ncea/iris/iris_documents/documents/toxreviews/0426tr.pdf. Accessed on 23 July 2016

IRIS (2011) Available from: http://cfpub.epa.gov/ncea/iris/index. cfm?fuseaction=iris.showSubstanceList. Accessed 24 July 2016

IRIS from US EPA (US Environmental Protection Agency) (2009) Drinking water standards and health advisories table. Available from: https://www3.epa.gov/region9/water/drinking/files/dwshatv09.pdf. Assessed on 27 June 2016

Isa NM, Aris AZ, Lim WY, Sulaiman WNAW, Praveena SM (2014) Evaluation of heavy metal contamination in groundwater samples from Kapas Island, Terengganu, Malaysia. Arab J Geosci 7(3):1087-1100

Jahanshahi R, Zare M (2015) Assessment of heavy metals pollution in groundwater of Golgohar iron ore mine area, Iran. Environ Earth Sci 74(1):505-520

Kim KW, Chanpiwat P, Hoang TH, Phan K, Sthiannopkao S (2011) Arsenic geochemistry of groundwater in Southeast Asia. Front Med 5(4):420-433
Krishna AK, Mohan KR, Murthy NN, Periasamy V, Bipinkumar G, Manohar K, Rao SS (2013) Assessment of heavy metal contamination in soils around chromite mining areas, Nuggihalli, Karnataka, India. Environ Earth Sci 70(2):699-708

Krishnamoorthy PS, Nagarajan K (2013) Levels of heavy metals in two rivers of Tamilnadu for predicting pollution loads. J Chem Biol Phys Sci 4(1):834-840

Li Z, Ma Z, van der Kuijp TJ, Yuan Z, Huang L (2014) A review of soil heavy metal pollution from mines in China: pollution and health risk assessment. Sci Total Environ 468-469:843-853

Li W, Wang MY, Liu LY, Wang HF, Yu S (2015) Groundwater heavy metal levels and associated human health risk in the North China Plain. Arab J Geosci 8:10389-10398

Lloyd JW, Heathcote JA (1985) Natural inorganic hydrochemistry in relation to groundwater. Clarendon Press, Oxford

Lu Y, Tang C, Chen J, Yao H (2016) Assessment of major ions and heavy metals in groundwater: a case study from Guangzhou and Zhuhai of the Pearl River Delta, China, vol 10. Frontiers of Earth Science, pp 340-351

Luo C, Liu C, Wang Y, Liu X, Li F, Zhang G, Li X (2011) Heavy metal contamination in soils and vegetables near an e-waste processing site, south China. J Hazard Mater 186:481-490

Martos FS, Bosch AP, Calaforra JM (1999) Hydrogeochemical processes in an arid region of Europe (Almeria, SE Spain). Appl Geochem 14:735-745

McCarty KM, Hanh HT, Kim K-W (2011) Arsenic geochemistry and human health in South East Asia. Rev Environ Health 26(1):71-78

Meunier JD, Riotte J, Braun JJ, Sekhar M, Chalié F, Barboni D, Saccone L (2015) Controls of DSi in streams and reservoirs along the Kaveri river, South India. Sci Total Environ 502:103-113

Nebergall WH, Schmidt FC, Holtzclaw HF (1963) College chemistry. DC Health and company, Boston, p 861

Nouri J, Mahvi AH, Jahed GR, Babaei AA (2008) Regional distribution pattern of groundwater heavy metals resulting from agricultural activities. Environ Geol 55:1337-1343

Planning Commission (2011) Report of the working group on rural domestic water and sanitation, Twelfth five year plan2012-2017, Ministry of Drinking Water and Sanitation, Government of India, p 220

Sabiha-Javied Mehmood T, Chaudhry MM, Tufail M, Irfan N (2009) Heavy metal pollution from phosphate rock used for the production of fertilizer in Pakistan. Microchem J 91(1):94-99

Shan Y, Tysklind M, Hao F, Ouyang W, Chen S, Lin C (2013) Identification of sources of heavy metals in agricultural soils using multivariate analysis and GIS. J Soils Sediments 13:720-729

Sharma RK, Agrawal M, Marshall F (2007) Heavy metal contamination of soil and vegetables in suburban areas of Varanasi, India. Ecotoxicol Environ Saf 66(2):258-266

Spurgeon DJ, Rowland P, Ainsworth G, Rothery P, Long S, Black HIJ (2008) Geographical and pedological drivers of distribution and risks to soil fauna of seven metals $(\mathrm{Cd}, \mathrm{Cu}, \mathrm{Cr}, \mathrm{Ni}, \mathrm{Pb}, \mathrm{V}$ and $\mathrm{Zn})$ in British soils. Environ Pollut 153(2):273-283

Stamatis G, Voudouris K, Karefilakis F (2001) Groundwater pollution by heavy metals in historical mining area of Lavrio, Attica, Greece. Water Air Soil Pollut 128(1):61-83

Thuong NT, Yoneda M, Ikegami M, Takakura M (2013) Source discrimination of heavy metals in sediment and water of to Lich River in Hanoi City using multivariate statistical approaches. Environ Monit Assess 185(10):8065-8075

Turekian KK (1968) Oceans. Prentice-Hall, Englewood Cliffs

UNDESA (United Nations Department of Economic and Social Affairs) (2013) World Population Prospects. Population Division Database. Detailed indicators 2012 Revision 
US EPA (1989) Risk assessment guidance for superfund, volume 1: human health evaluation manual (part A) ((EPA/540/1-89/002: interim final). Washington DC: Office of Emergency and Remedial Response

US EPA (1994) Water quality standards handbook: 2nd ed. EPA-823B-94-005a,b. National Technical Information Service, Springfield, VA

US EPA (2014) Drinking Water Contaminants. Available from: https://www.epa.gov/ground-water-and-drinking-water/tableregulated-drinking-water-contaminants. Accessed on 1 July 2016

US EPA (2016) Lithium, Virginia Department of Health, USA. Available from: http://www.vdh.virginia.gov/content/uploads/ sites/12/2016/02/Lithium2014.pdf. Accessed on 24 July 2016

US EPA from CHMP (Committee for Human Medicinal Products) (2007) Guidelines on the specification limits for residues of metal catalysts. Doc. Ref. CPMP/SWP/QWP/4446/00 corr. Available from: http://www.ema.europa.eu/docs/en_GB/document_library/ Scientific_guideline/2009/09/WC500003587.pdf. Assessed on 27 June 2016

Varol M (2011) Assessment of heavy metal contamination in sediments of the Tigris River (Turkey) using pollution indices and multivariate statistical techniques. J Hazard Mater 195:355-364

Varol M, Şen B (2012) Assessment of nutrient and heavy metal contamination in surface water and sediments of the upper Tigris River, Turkey. Catena 92:1-10

Vetrimurugan E, Elango L (2015) Groundwater chemistry and quality in an intensively cultivated river delta. Water Qual Expo Health. doi:10.1007/s12403-014-0133-7
Vetrimurugan E, Elango L, Rajmohan N (2013) Sources of contaminants and groundwater quality in the coastal part of a river delta. Int J Environ Sci Technol 10:473-486

Viridor Waste Ltd (2009). Viridor New England energy from waste project: Technical data for HHRA generic assessment criteria (402-0036-00350). Available from: http://www.devon.gov.uk/ plandoc259_4975.pdf. Accessed 1 July 2016

WHO (World Health Organisation) (2011) Guidelines for drinking water quality, 4th edn. WHO, Geneva

WHO (1993) Guidelines for drinking water quality, vol. 1, 2nd edn, Recommendations, WHO, Geneva, p 130

Wongsasuluk P, Chotpantarat S, Siriwong W, Robson M (2014) Heavy metal contamination and human health risk assessment in drinking water from shallow groundwater wells in an agricultural area in Ubon Ratchathani province, Thailand. Environ Geochem Health 36(1):169-182

Xu B, Xu Q, Liang C, Li L, Jiang L (2015) Occurrence and health risk assessment of trace heavy metals via groundwater in Shizhuyuan Polymetallic Mine in Chenzhou City, China. Front Environ Sci Eng 9(3):482-493

Yousaf B, Liu G, Wang R, Imtiaz M, Rizwan MS, Zia-ur-Rehman M, Qadir A, Si Y (2016) The importance of evaluating metal exposure and predicting human health risks in urban-periurban environments influenced by emerging industry. Chemosphere 150:79-89

Zhao H, Xia B, Fan C, Zhao P, Shen S (2012) Human health risk from soil heavy metal contamination under different land uses near Dabaoshan Mine, Southern China. Sci Total Environ 417-418:45-54 